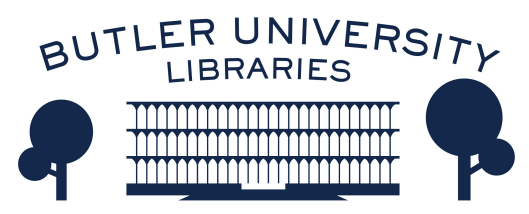

Journal of Hindu-Christian Studies

\title{
The Limits of Theodicy: An Eastern Orthodox Perspective on Evil and Interreligious Theology
}

Rico G. Monge

University of San Diego

Follow this and additional works at: https://digitalcommons.butler.edu/jhcs

Part of the Christianity Commons, Comparative Methodologies and Theories Commons, Hindu Studies Commons, and the Religious Thought, Theology and Philosophy of Religion Commons

\section{Recommended Citation}

Monge, Rico G. (2016) "The Limits of Theodicy: An Eastern Orthodox Perspective on Evil and Interreligious Theology," Journal of Hindu-Christian Studies: Vol. 29, Article 6.

Available at: https://doi.org/10.7825/2164-6279.1629

The Journal of Hindu-Christian Studies is a publication of the Society for Hindu-Christian Studies. The digital version is made available by Digital Commons @ Butler University. For questions about the Journal or the Society, please contact cbauman@butler.edu. For more information about Digital Commons @ Butler University, please contact digitalscholarship@butler.edu. 


\title{
The Limits of Theodicy: An Eastern Orthodox Perspective on Evil and Interreligious Theology
}

\author{
Rico G. Monge \\ University of San Diego
}

THIS essay is written from the vantage point of a comparative theologian who is personally steeped in the Eastern Orthodox Christian tradition and who primarily specializes in Christian-Muslim comparative theology. It might seems curious, then, that the present essay employs the comparative theological method in order to focus on questions of theodicy in the Christian and Hindu traditions. Perhaps even more curious, however, is that I aim not at articulating a comparative ChristianHindu theodicy, but rather at suggesting that the most productive path forward is a comparative theological rejection of theodicy as a productive enterprise. Drawing from resources within my own Orthodox Christian tradition, as well as from the thought of Paul Ricoeur, my essay will revolve around two primary arguments: first, theodicy functions primarily to reconcile human beings to evil's existence, thus legitimizing it and reducing the need to counteract evil; and second, religious traditions more effectively encounter the question of evil by teaching a path by which practitioners can mourn, reject, combat, and transform evil. Accordingly, I will first briefly examine two salient instances of comparative Christian-Hindu theodicy in order to demonstrate how my approach differs. Next, I will engage with key critics of theodicy, some of whom are skeptical of religion (or even hostile to it), and some of whom are religious adherents who maintain theodicy is an inherently deleterious mode of thought. I will conclude by drawing from both Fyodor Dostoevsky and Paul Ricoeur in order to suggest a more productive trajectory for comparative theology and the challenges posed by the existence of evil and suffering.

Theodicy in its most narrow sense is a distinctive feature of the Abrahamic monotheisms, perhaps Christianity most of all.

Rico G. Monge's teaching and research focuses on comparative theology, continental philosophy of religion (including theodicy), and the history of Christian theology (including Catholic, Protestant, and Eastern Orthodox theology). As a comparative theologian, Monge specializes in Christian and Islamic mystical and ascetic traditions. Holding degrees in literature, theology, and religious studies, he also explores religious and philosophical themes in literature and film. He is the founding co-chair of the Catholic Studies Group of the American Academy of Religion's Western Region and an associate editor of the journal Medieval Mystical Theology. He has recently published the edited volume, Hagiography and Religious Truth: Case Studies in the Abrahamic and Dharmic Traditions (Bloomsbury, 2016). Monge is also an ordained deacon in the Eastern Orthodox Church. 
The Limits of Theodicy: An Eastern Orthodox Perspective on Evil and Interreligious Theology 37

John Milton's Paradise Lost is theodicy in the form of an epic poem, for, as Milton plainly states, his goal is to "justify the ways of God to men." " The term theodicy itself, coined by Gottfried Wilhelm Leibniz, etymologically suggests that the purpose is to render a satisfactory justification of God. ${ }^{2}$ In this narrow and culturally specific sense, then, theodicy is particularly a problem for the Abrahamic monotheisms, all of which maintain that there is only one God-and that this God is both omnibenevolent and omnipotent. ${ }^{3}$ If these tenets are held to be so, theodicy becomes a particular difficulty, for as David Hume (and others) have succinctly put it, "Is [God] willing to prevent evil, but not able? Then is he impotent. Is he able but not willing? Then is he malevolent. Is he both able and willing? Whence then is evil?" While Hume means this to be a skeptic's attack on the impossibility of a satisfactory Christian theodicy, the issues he raises are the very issues that Christian (and Islamic and Jewish theologians) have grappled with for millennia.

Nevertheless, while the term theodicy has culturally specific origins in the philosophical and theological traditions of Abrahamic monotheism, meaningful attempts to explain the existence of evil and suffering exist in every major religious tradition. Francis X. Clooney, for example, has engaged in nuanced comparative theodicy between the Christian and Hindu traditions. In his focused study on Vedanta Desika and Thomas Aquinas, he argues that despite their significant differences, "There is no reason not to see Desika and Aquinas as allies sharing the same goal of putting evil back in its subordinate place, giving meaning to suffering and hope to those who suffer, more forcefully extolling the goodness of God, and, in the end, bolstering a comparative project that uses discourses on evil for the sake of a even greater good than the one that either theological tradition could have envisioned on its own." ${ }^{5}$ In doing so, Clooney highlights the practical import of theodicy; it does not serve primarily simply to render belief in God/gods logically coherent, but also to: 1) "put evil in its place"; 2) grant meaning to suffering; 3 ) give hope to the suffering; 4) justify the goodness of God; and 5) promote the good. Clooney's analysis here is deeply insightful concerning the roles theodicy overtly plays for the religious insider. We shall return to the difficulties created by this classical approach below. In order to transition there, we must first examine Clooney's interaction with Peter Berger on the question of theodicy in a Hindu context.

In his 1989 article focused on Vedanta's theology of Karma, Clooney adds much-needed theological nuance to Berger's sociological reading of the kind of theodicy "karmasamsara" provides. ${ }^{6}$ Drawing from Max Weber, Berger argues that theodicies exist on a spectrum of how highly "rationalized" they are, and argues that the principle of karma-samsara in the dharmic religious traditions stands at the most highly rationalized pole. Clooney notes that Berger does not "directly engage Vedanta thinking" in his analysis and thus misses that the Vedantic perspective is "not rationalistic," "frustrates reason's quest for a neat explanation by maintaining the irreconcilable poles of freedom and predestination," and mitigates the mechanistic aspects of karma by "reserving to brahman-who is pure intelligence and being and joy-the efficacy of the system," thereby ensuring "that humans are not hopelessly lost in the system or at the mercy of impersonal forces." "In short, Clooney argues that Vedantic 
thinking accomplishes the classic goals of theodicy outlined in the paragraph above. While Clooney is correct that a more nuanced understanding of Vedanta would shift karmasamsara's location on Berger's spectrum, Clooney's analysis also paradoxically reinforces that Vedantic theodicy is subject to the critiques leveled by Berger (as well as the critiques of the thinkers to whom Berger is most deeply indebted, Weber, Karl Marx, and Friedrich Nietzsche).

Indeed, the very fact that Clooney places Vedanta Desika and Thomas Aquinas so closely together itself strongly suggests Berger's crosscultural analysis of the function of theodicy remains as potent as ever. For Berger's primary contention is that theodicy is central to a religion's ability to create a "sacred canopy" that binds a culture together and affords it some protection against the otherwise meaningless chaos of the universe. For Berger, theodicy is thus not ultimately about justifying God's goodness to human beings, but, rather, "the legitimation of anomic phenomena." 8 Put otherwise, Berger argues that sociologically, theodicy functions to legitimize why things that cultural norms and expectations would dictate "should not happen," do, in fact, happen all the time. Theodicy thus provides the way for human beings to accept why the "anomic" or "evil" can occur. Even more problematic, systems of theodicy provide paths by which these occurrences can further be understood as both legitimate and necessary. Four of the five points I distilled from Clooney's comparison of Desika and Aquinas thus demonstrate Berger's point; theodicy provides human beings with the reassurance and hope that things are as they should be, and, further, that they will work for the best according to a higher plan. If 1) evil has been "put in its place"; 2) suffering has been granted meaning; 3) hope has been given to those who suffer; and 4) the goodness of God has been justified, has Berger not been largely vindicated? Evil has certainly not been "put in its place" other than intellectually. Granting meaning to suffering renders suffering "moralized" according to Nietzsche's most potent critiques, potentially redoubling the guilt of those who are already suffering and unable to convert that suffering into moral benefit. ${ }^{9}$ Providing hope to the suffering, if this comes without addressing and eradicating the root causes of suffering, offers little more than what Marx aptly identified as the "opiate of the masses." ${ }^{10}$ Finally, "justifying the ways of God to men" is, by definition, the attempt to legitimize-even valorize-why an omnibenevolent and omnipotent God permits so much suffering and evil.

We will return to Clooney's fifth point, "to promote the good," at the end of this essay. For now, let us investigate further the question concerning whether theodicy is helpful or harmful to religions themselves, and, more importantly, to their adherents. Western Christian (i.e. Catholic and Protestant) theodicy from Augustine to Leibniz (arguably its most sophisticated expositor) has revolved around these very objectives of providing reassurance and hope to human beings, and thus to reconcile them to the fact that evil and suffering exist. Augustine agonizes over why evil could exist throughout his Confessions, finally concluding that it is Christianity that offers the only satisfactory answer. For him, the resolution (or in Berger's terms "legitimation") of evil is to be found in his twin arguments that 1) evil does not exist, but is a falling away from God who is pure Being, and 2) that human beings possess free 
will such that even our falling away towards non-Being is not God's fault but ours. ${ }^{11}$ Several centuries later, Thomas Aquinas adhered closely to Augustinian theodicy while tackling the thorny issue of causality and responsibility. For Aquinas, God's role as providential creator means that God is, in a certain causal sense, the origin of evil (and human free will is not sufficient to erase that fact). Free will, however, ensures that "God is responsible for sinful actions, but not for sins," or, in other words, God is causally responsible but not morally responsible for evil. ${ }^{12}$ Leibniz, working out this paradox even more rigorously, posited that this world is the best of all possible worlds "not only for all in general, but for each one of us in particular." ${ }^{13}$ In each of these pivotal figures the bottom line affirms both Clooney's and Berger's analyses concerning the function of theodicy. And lest I give the impression that Eastern Christianity is immune to or free from engaging in theodicy, one need only look at Dionysius the Areopagite's The Divine Names and John of Damascus's The Orthodox Faith for recapitulations of Augustinian theodicy. ${ }^{14}$ Even John Hick's exposition of Irenaeus of Lyons's theodicy shows a deep Eastern Christian affinity for the idea that evil and suffering are necessary for moral growth. ${ }^{15}$ We shall return to the question of Irenaean theodicy in the discussion of Ricoeur below.

One might naturally ask at this point, "so what's the problem with theodicy?" For Friedrich Nietzsche and Max Weber, theodicy demonstrates the human desire to impose meaning and value on what would otherwise be senseless and random suffering. This endeavor to use human rational faculties to create meanings for suffering that are not actually there reflects a childish inability to accept the world as it actually is. It devalues the world and our present lives by deferring existence as it "should be" to the next life. ${ }^{16}{ }^{17}$ Building upon Nietzsche and Weber, Berger, as we have seen, argues that theodicy serves to make us reconciled to the "anomic" phenomena we would otherwise categorically reject. In the wake of the horrors of the $20^{\text {th }}$ century, many Christian theologians are beginning to recognize these deleterious aspects of theodicy's core functions. Karen Kilby, for example, argues that Christianity should not be engaged in theodicy, that theodicy has nothing to do with the Gospel of Jesus Christ, and that theodicy makes us less likely to feel compelled to carry out one of the primary duties of the Christian: to combat evil. ${ }^{18}$ Moreover, Sarah Katherine Pinnock has gathered together contributions from leading Christian and Jewish philosophers in an effort to move "beyond theodicy," not because theodicy is inadequate to make sense of the horrors of the Holocaust/Shoah (Leibniz would indeed have an "adequate" answer), but because making sense of it, rendering it meaningful, and thus legitimizing its occurrence is not remotely desirable. $^{19}$

What then should be done? Are theology and religion separable from theodicy? As Clooney observes with Desika, theodicy does not always provide neat answers, and both Christianity and Hinduism have robust mystical traditions asserting the ultimate unknowability of the divine. Does emphasis on divine incomprehensibility escape the problems wrought by theodicy? David Hume, Ludwig Feuerbach, and Sigmund Freud each argue that while recourse to unknowability may indemnify God from critique, it also eradicates the very thing-theodicy-that, in their views, makes 
religion attractive to human beings in the first place. Hume, for example, maintains that those who uphold the unknowability of God are "atheists without knowing it." 20 Similarly, Feuerbach claims that the "theory that God cannot be defined, and consequently cannot be known by man, is therefore the offspring of recent times, a product of modern unbelief." ${ }^{21}$ Freud draws out the practical implications rather succinctly when he asserts, "If you confine yourself to the belief in a higher spiritual being, whose qualities are indefinable and whose intentions cannot be discerned, then you are proof against the interference of science, but then you will also relinquish the interest of men." 22 Stripped of the hope, comfort, and security that theodicy's legitimations provide, religion will lose its psychological appeal for the majority of human beings. Augmenting these philosophical and psychological ruminations, Berger employs empirical sociological evidence to demonstrate that the decline of a religion's plausibility is directly proportional to the devaluation of its corresponding theodicy. ${ }^{23}$ It would seem then that religion can survive neither with theodicy nor without it.

The writings of Fyodor Dostoevsky and Paul Ricoeur present other options, however, ones that are particularly promising for comparative theological engagement with evil and suffering. Curiously enough, their approaches have significant resonances with aspects of Freudian thought. ${ }^{24}$ In The Brothers Karamazov, Dostoevsky famously enlists the character of Ivan Karamazov to utterly destroy theodicy in the chapters entitled "Rebellion" and "The Grand Inquisitor." Quite strikingly, however, Ivan's devout brother (and novice monk) Alyosha accepts Ivan's dismantling of Christian theodicy without abandoning his faith. ${ }^{25}$ Furthermore, Alyosha's spiritual father, the Elder Zosima, nowhere engages in theodicy, including the section of the novel (Book VI: The Russian Monk) that Dostoevsky openly referred to as his response to Ivan. ${ }^{26}$ Instead of a theodicy that would impose meaning on evil and suffering in order to render them "legitimate," Alyosha and Zosima embody a way of being in the world that combats evil through radical love-a love that has the power to transfigure everything it touches. When Alyosha asserts that the love of life is of the utmost importance, Ivan is incredulous and suggests that understanding the meaning of life is still more important, because only if life is meaningful is it lovable. Alyosha's pivotal response is that he must love life first of all "and only then will I also understand its meaning." ${ }^{27}$ The reversal here is more profound in its implications than it might seem at first. For Alyosha, evil and suffering are not things to be comprehended, tamed, and rendered acceptable through logical, discursive explanations. Rather, it is love, not logic, which infuses existence with meaning and empowers one to combat and transform evil and suffering, rather than concocting an explanation for why it exists.

This power of radical love is demonstrated throughout Zosima's discourses in "The Russian Monk," but perhaps nowhere more poignantly than in the story of his older brother Markel, who died of tuberculosis while still a teenager. Previously a skeptic, Markel undergoes a dramatic conversion in which he is filled with love for all of existence-for his fellow human beings as well as for the natural world. Nowhere does Markel seek (or find) a rational explanation for why such a terrible fate should befall him. When his doctor lies to him stating he will live 
for a long time yet, Markel dismisses the length of his life as irrelevant: "But what are years, what are months! .... Why count the days, when even one day is enough for a man to know all happiness? My dears, why do we quarrel, boast before each other, remember each other's offenses? Let us go to the garden, let us walk and play and love and praise and kiss each other and bless our life." ${ }^{28}$ Even more forcefully, Markel asserts that such love reveals that "life is paradise, but we do not want to know it, and if we did want to know it, tomorrow there would be paradise the world over." ${ }^{29}$ Nevertheless, nowhere does Markel engage in even an Irenaean theodicy that would moralize and validate his deadly illness because it allowed him to achieve this all-encompassing love. On the contrary, it is the transfiguring power of love that renders the question "Why me?" utterly irrelevant.

As compelling as Markel's story may be, Dostoevsky was a man intimately acquainted with the depths of human suffering, and Markel's example alone does not convey the fullness of Dostoevsky's response to Ivan's destruction of theodicy. Equally crucial are Zosima's ruminations on the book of Job. While Job is often viewed as the supreme example of Judeo-Christian scriptural theodicy, Zosima instead reads the text as a sort of manual in learning how to grieve over suffering and evil. Indeed, Zosima notes that the story of Job, read as a theodicy explaining evil, is both ludicrous and offensive. "How could the Lord hand over the most beloved of his saints for Satan to play with him, to take away his children, to smite him with disease and sores so that he scraped the pus from his wounds with a potsherd, and all for what? Only so as to boast before Satan: 'See what my saint can suffer for my sake!"” ${ }^{30}$ Rejecting this reading, Zosima asserts "what is great here" in the book of Job is its demonstration of the possibility of healing in which "old grief, by a great mystery of human life, gradually passes into quiet, tender joy." ${ }^{31}$ To sum up, what Dostoevsky shows us is the power of Christianity not to explain evil and suffering, but rather to combat it, transform it, and to learn how to productively grieve over it.

Though not himself Orthodox, the Protestant Paul Ricoeur likewise rejects theodicy and expresses an ethos that resonates heavily with Doestoevsky's Orthodoxy. In his essay, "Evil, a Challenge to Philosophy and Theology," Ricoeur surveys the history of Christian theodicy and critiques it heavily for the same reasons expressed throughout this essay. He then sets forth his alternative vision of how the texts of the Bible address the challenge of evil. Rather than offering a logical explanation of evil subject to "both the rule of noncontradiction and that of systematic totalization," Ricoeur argues that Biblical texts instead (1) enjoin us to act against evil, and (2) offer us a five-stage path of wisdom through which we can learn how to grieve. ${ }^{32}$ Contrary to theodicy, which asks "whence comes evil," Ricoeur argues, "the response, not the solution, of action is to act against evil. Our vision is thus turned toward the future, by the idea of a task to be accomplished." ${ }^{33}$ Ricoeur thus argues that Biblical texts offer hope, but a hope that imposes a responsibility on us. The potential of theodicy to make us complacent towards the evil it legitimizes is thereby removed, and in its place stands the burden to fight against evil with all our might. But Ricoeur also recognizes that action against evil is not enough in and of itself. This is because evil is not merely something one "commits"; evil is also something one undergoes 
and from which one suffers intense trauma and grief.

For this reason, Ricoeur sets forth the fivestage path he has gleaned from the Christian scriptures for learning how to grieve. In doing so, Ricoeur acknowledges he is also indebted to Freud's essay "Mourning and Melancholia." In the first stage of this "work of mourning," Ricoeur advocates for the exact opposite of theodicy-the admission of ignorance. Only in admitting to ourselves that we cannot make sense of suffering can we begin to heal from it. From this first stage of ignorance, we can then move to a second, perhaps even more surprising stage: complaint against God. It must be stressed that Ricoeur is not abstractly philosophizing here; he is following the example set forth by the psalmists who both profess ignorance of why evil happens, and, at times, rage against God for the fact that it does happen. Only by passing through genuine rage can we come to the third stage, the realization that theodicy is not the reason or precondition for belief. Instead, we come to find that "suffering is only a scandal for the person who understands God to be the source of everything that is good in creation, including our indignation against evil, our courage to bear it, and our feeling of sympathy toward victims. In other words, we believe in God in spite of evil." ${ }^{34}$ We find ourselves here far from both the security blanket offered by theodicy and from the poor refuge of the unknowable God (and practical atheism) critiqued by Hume, Feuerbach, and Freud.

We might here pause for a moment to ask whether we have become too polemical and thus blind to some of the insights theodicy genuinely has to offer. Does not the educative, Irenaean model of theodicy have some truth to it, at least? In the fourth and fifth stages of learning how to mourn, Ricoeur (and I) would answer with a cautious "yes." In the fourth stage, a person may come to a place where they discern in suffering "some educative and purgative value." ${ }^{35}$ The crucial distinction between this fourth stage and theodicy is that the fourth stage does not signify the construction of a totalizing system. The ability to discern educative value in suffering is neither an imperative to discover it, nor the assertion that such educative value necessarily exists in every instance of suffering. The fourth stage allows the individual to work out the particulars of his or her own grief, whereas theodicy runs the risk of "leading the victim back along the route of self-accusation or self-destruction." ${ }^{36}$ In other words, it is good and proper to affirm what value a person can come to find in his or her suffering, while it is harmful and cruel to impose on each person the imperative to find meaning and value in suffering. In the final stage along the path of wisdom, one may ultimately come to "love God for naught" just as Job does at the end of his tale of unfathomable suffering. In reaching this stage, a person can find an extraordinary degree of liberation and power over suffering and evil. As Ricoeur puts it, "to love God for naught is to escape completely the cycle of retribution to which the lament [of stages 1-3] remains captive, so long as the victim bemoans the injustice of his or her fate." 37 Again, it cannot be stressed enough that this is neither a moral imperative nor an explanation of the "purpose" of evil. The fifth stage is about reaching a place of liberation and empowerment that has no need of theodicy whatsoever.

Ricoeur concludes his essay with a suggestion for a productive future trajectory for interreligious reflection upon evil and suffering. Having laid out his reading of the five-stage path 
of Judeo-Christian wisdom, he suggests, "perhaps this horizon of wisdom, at least as it appears in the West under the influence of Judaism and Christianity, overlaps the horizon of Buddhist wisdom at a significant crossing point that only a long dialogue between them could make more conspicuous...." 38 While Ricoeur, without explanation, specifies Buddhism here as a dialogue partner, it should be clear that the same sentiment would hold true for Vedantic wisdom. How might karmasamsara show up radically differently if we were to focus on how it guides adherents in combatting evil and learning how to mourn? How might comparative theological engagement along these lines yield real, practical value in dealing with evil and suffering? With Ricoeur, I suggest this is the most productive path forward in interreligious engagement with the question of evil.

The time is ripe for further comparative investigations of the wisdom by which religious traditions guide adherents in the face of evil. In doing so, we will not only avoid the dangers and pitfalls of theodicy, we will almost assuredly empower people of all faith traditions to more effectively confront the evil and suffering that comes to us all. How might the insights of Clooney's fifth point, "to promote the good," come to greater fruition through Hindu-

\section{Notes}

${ }^{1}$ John Milton, Paradise Lost, in The Riverside Milton, ed. Roy Flannigan (New York: Houghton Mifflin, 1998), book 1 , line 26.

${ }^{2}$ See Leibniz, Theodicy: Essays on the Goodness of God the Freedom of Man and the Origin of Evil, trans E.M. Huggard (New York: Cosimo Classics, 2010).

3 In Greco-Roman paganism, for example, theodicy is still operative, but with far fewer logical problems. If people are devotees of Poseidon in a sea
Christian reflection on evil and suffering? I will close this essay by highlighting one recent constructive work of theology from within the Hindu tradition, Anantanand Rambachan's A Hindu Theology of Liberation: Not-Two Is Not One. ${ }^{39}$ Like Dostoevsky and Ricoeur, Rambachan is wary of the way the term "theology" has been used in the past, as well as the role it has played in legitimizing suffering rather than promoting the good and strengthening the ability of religious practitioners to combat evil, be liberated from suffering, and to learn to grieve in ways that do not further compound one's suffering. ${ }^{40}$ For Rambachan, the role of theology is not to provide a theodicy that legitimizes evil by "problematizing the world," but, rather, to bring about "liberation." In his words, "Liberation is a new understanding of self and world. The consequence of knowing oneself to be a full being is freedom from greed. One shares the most profound identity with all beings when one knows oneself to be the self of all. Wisdom blossoms in compassion, that is, the seeing of oneself in the sorrows and joys of others, in generosity, and in self-control." ${ }^{41}$ With Clooney, Dostoevsky, Ricoeur, and Rambachan, a new future for comparative and interreligious theological reflection is upon us-provided we can continue to escape the limits and pitfalls of theodicy.

village and their homes and lives are ravaged by a tsunami, the gods are neither omnibenevolent nor omnipotent. Poseidon could have chosen to do this simply because he does not like his devotees. Moreover, an antagonist of Poseidon (e.g. Athena) could have been taking out her frustration with the village for aligning with Poseidon instead of her. 
4 David Hume, Dialogues Concerning Natural Religion, in Dialogues and Natural History of Religion (Oxford: Oxford University Press, 2008), 100.

${ }^{5}$ Francis X. Clooney, "For Your Own Good": Suffering and Evil in God's Plan according to One Hindu Theologian," in Deliver Us From Evil: Boston University Studies in Philosophy and Religion, eds. M. David Eckel and Bradley L. Herling, (London: Bloomsbury Academic, 2011), 184.

${ }^{6}$ Peter Berger, The Sacred Canopy: Elements of a Sociology of Religion (New York: Anchor Books, 1990), 65-67.

${ }^{7}$ Francis X. Clooney, "Evil, Divine Omnipotence, and Human Freedom: Vedanta's Theology of Karma," The Journal of Religion 69 (4): 535. http://dx.doi.org/10.1086/488203

${ }^{8}$ Berger, The Sacred Canopy, 55.

${ }^{9}$ See esp. the third essay of Friedrich Nietzsche's On the Genealogy of Morals, in On the Genealogy of Morals and Ecce Homo, trans. by Walter Kaufmann and R.J. Hollingdale (New York: Vintage Books, 1989).

${ }^{10}$ Karl Marx, Critique of Hegel's Philosophy of Right, trans. Joseph O'Malley (Madurai, India: Leopard Books, 2015), 7-8.

${ }^{11}$ Augustine of Hippo, Confessions, trans. John K. Ryan (New York: Image Books, 1960). See especially sections 7.4.6, 7.7.11, 7.11.17, 7.12.18, 3.7.12, and 7.15.21.

${ }^{12}$ Thomas Aquinas, Summa contra Gentiles, in Selected Philosophical Writings, trans. Timothy McDermott (Oxford: Oxford University Press, 1993), 296.

${ }^{13}$ Gottfried Leibniz, Monadology in Discourse on Metaphysics and Monadology, trans. George R. Montgomery (New York: Cosimo Classics, 2008), 88.

${ }^{14}$ John of Damascus, Exposition of the Orthodox Faith, trans. S.D.F. Salmond (London: Aeterna Press, 2016), 159; and Pseudo-Dionysius, The Divine Names, in Pseudo-Dionysius: The Complete Works, trans. Colm Luibheid (Mahwah, NJ: Paulist Press, 1987), especially sections 4.18-4.35.

${ }^{15}$ John Hick, Evil and the God of Love (New York: Palgrave Macmillan, 2010), 211-235.
${ }^{16}$ See, for example, Friedrich Nietzsche, The Twilight of the Idols, in The Twilight of the Idols/The AntiChrist, trans. R.J. Hollingdale (London: Penguin, 1990), "Expeditions of an Untimely Man" \$45, p.110; On the Genealogy of Morals, in On the Genealogy of Morals and Ecce Homo, trans. by Walter Kaufmann and R.J. Hollingdale, (New York: Vintage Books, 1989), \$3.1; and The Will to Power, trans. by Walter Kaufmann and R.J. Hollingdale (New York: Vintage Books, 1968) §12.

${ }^{17}$ Max Weber, "Politics as a Vocation," in From Max Weber: Essays in Sociology, trans., ed. and with an intro. by H.H. Gerth and C. Wright Mills, 77-128 [New York: Oxford University Press, 1958]: 122, 126). Weber, "The Social Psychology of the World's Religions," in From Max Weber: Essays in Sociology, 271. Weber, "Religious Rejections of the World and Their Directions," in From Max Weber: Essays in Sociology, 353.

${ }^{18}$ Karen Kilby, "Evil and the Limits of Theodicy," New Blackfriars 84 (2003): 13-29. http://dx.doi.org/ 10.1111/j.1741-2005.2003.tb06484.x

${ }^{19}$ Sarah Katherine Pinnock, Beyond Theodicy: Jewish and Christian Continental Thinkers Respond to the Holocaust (Albany, NY: SUNY Press, 2002). It is worth noting here that many Jewish thinkers have shifted from using the word Holocaust (a "sacrificial burnt offering") to the word Shoah ("the catastrophe") in order to reject the theodicy implied within the term Holocaust.

${ }^{20}$ David Hume, Dialogues Concerning Natural Religion, in Dialogues and Natural History of Religion (Oxford: Oxford University Press, 2008), 61.

${ }^{21}$ Ludwig Feuerbach, The Essence of Christianity, trans. George Eliot, (Mineola, NY: Dover Philosophical Classics, 2008), $\mathrm{x}$.

${ }^{22}$ Sigmund Freud, The Future of an Illusion, trans. W.D. Robson-Scott (Mansfield, CT: Martino Publishing, 2010), 94. See also Freud's observations in Civilization and Its Discontents, trans. James Strachey (New York: W.W. Norton, 1961), 22-23.

${ }^{23}$ Berger, The Sacred Canopy, 78-80.

${ }^{24}$ These resonances with Freud should not be entirely surprising, given Freud's extremely high regard for Dostoevsky and Ricoeur's selfidentification as a Christian "master of suspicion" 
The Limits of Theodicy: An Eastern Orthodox Perspective on Evil and Interreligious Theology 45

standing in the critical tradition of Marx, Nietzsche, and Freud.

${ }^{25}$ Fyodor Dostoevsky, The Brothers Karamazov, trans. Richard Pevear and Larissa Volokhonsky (New York: Farrar, Straus and Giroux, 2002), 288-290.

${ }^{26} \mathrm{See}$, for example, Harold Bloom's inability to make sense of Book VI: The Russian Monk because he erroneously searches in vain for a compelling theodicy within it. Bloom, "Introduction" to Modern Critical Interpretations: Fyodor Dostoyevsky's The Brothers Karamazov, ed. and with an intro. by Harold Bloom, (New York: Chelsea House, 1988).

${ }^{27}$ Dostoevsky, The Brothers Karamazov, 231.

${ }^{28}$ Ibid., 289.

${ }^{29}$ Ibid., 288.

${ }^{30}$ Ibid., 292.
${ }^{31}$ Ibid.

${ }^{32}$ Paul Ricoeur, "Evil, a Challenge to Philosophy and Theology," in Figuring the Sacred: Religion, Narrative, and Imagination, trans. David Pellauer (Minneapolis, MN: Fortress, 1995), 249, 251-252.

${ }^{33}$ Ibid., 259.

${ }^{34}$ Ibid., 260.

${ }^{35} \mathrm{Ibid}$.

${ }^{36}$ Ibid., 260-261.

${ }^{37}$ Ibid., 261.

${ }^{38}$ Ibid.

${ }^{39}$ Anantanand Rambachan, A Hindu Theology of Liberation: Not-Two Is Not One (Albany, NY: SUNY Press, 2015).

${ }^{40}$ Ibid., 2-6.

${ }^{41}$ Ibid., 188. 